osmotic diuresis, or from an increase in the sodium filtered charge, which is related to the rise in serum sodium concentration.

Identical results might have been obtained with an osmotic diuresis using mannitol. A certain difference, however, exists between the two osmoles. Mannitol must be given intravenously because it cannot be absorbed intestinally. As mannitol cannot enter cells a circulatory overload may result with an attendant risk of cardiac failure, particularly if subclinical alcoholic cardiomyopathy already exists. Mannitol will transiently worsen hyponatraemia, and the combination of mannitol with frusemide has recently been reported to be nephrotoxic. ${ }^{5}$

In patients with a history of severe gastric disorders urea can be given intravenously. Intermittent treatment with urea could be useful in the management of some hyponatraemic and combined ascitic cirrhotic conditions without extrarenal uraemia which do not respond to diuretics.

We thank the Ministere de la Politique Scientifique (Actions concertées) for financial assistance.

1 Perez-Ayuso RM, Arroyo V, Camps J, et al. Effect of demeclocycline on renal function and urinary prostaglandin $\mathrm{E}_{2}$ and kallikrein in hyponatremic cirrhotics. Nephron 1984;36:30-7.

2 Decaux G, Genette F. Urea for long term treatment of the syndrome of inappropriate secretion of antidiuretic hormone. Br Med $\mathcal{F}$ 1981;283:1081-3.

Decaux G. Treatment of the syndrome of inappropriate secretion of antidiuretic hormone by long loop diuretics. Nephron 1983;35:82-8.

4 Stanley MM. Treatment of intractable ascites in patients with alcoholic cirrhosis by peritoneovenous shunting (Le Veen). Med Clin North Am 1979;63:523-36. et furosemide. Nouv Presse Med 1981;10:1744-5. Accepted 18 fanuary 1985)

Department of Internal Medicine, Hôpital Universitaire Erasme, Free University of Brussels, 1070 Bruxelles, Belgium G DECAUX, MD, PHD

P MOLS, MD

Institute of Interdisciplinary Research, School of Medicine, Free University of Brussels

P CAUCHI, MD

F DELWICHE, MD

Correspondence to: Dr G Decaux.

\section{Intolerance of bromocriptine: is metergoline a satisfactory alternative?}

Bromocriptine, a dopamine agonist, is often used to treat patients with hyperprolactinaemia. In some patients tolerance to bromocriptine is poor and the drug has to be stopped because of nausea and vomiting. Metergoline (8- $B$-carbobenzyl-ossiaminomethyl- 1 , 6-dimethyl-10-alpha-ergoline), a serotonin antagonist, has been used elsewhere in Europe to suppress puerperal lactation, ${ }^{1}$ but there have been few clinical trials of metergoline in hyperprolactinaemia or normoprolactinaemic galactorrhoea. This preliminary report describes our clinical experience of using metergoline as an alternative treatment in patients intolerant of bromocriptine.
Patients, methods, and results

Metergoline was obtained on a named patient basis after informed consent was given by 14 patients (three men and 11 women) who had hyperprolactinaemia or normoprolactinaemic galactorrhoea and were intolerant of bromocriptine. Patients received an increasing dose of metergoline over two weeks, starting at $2 \mathrm{mg}$ once daily and progressing to $4 \mathrm{mg}$ three times daily. At monthly reassessment the dose was increased to $16 \mathrm{mg}, 20 \mathrm{mg}$, or $24 \mathrm{mg}$ in divided doses according to response, the minimum dose required to maintain the plasma prolactin concentration below $480 \mathrm{mU} / 1$ being given. Plasma concentrations of prolactin, urea, creatinine, cholesterol, and electrolytes, liver enzyme activities, and full blood count were measured monthly. Plasma progesterone concentration was measured on day 20, 21 , or 22 if the patient was menstruating regularly.

The three men had each undergone pituitary surgery and radiotherapy for prolactinoma but still had raised plasma prolactin concentrations (mean of three estimations before metergoline in each patient $78000 \mathrm{mU} / \mathrm{l}$, $25000 \mathrm{mU} / 1$, and $12000 \mathrm{mU} / \mathrm{l})$. Plasma prolactin concentration was reduced, though not to normal, in all patients (mean of concentrations at five, six, and seven months after the start of metergoline: $5200 \mathrm{mU} / 1,9100 \mathrm{mU} / \mathrm{l}$, and $8210 \mathrm{mU} / 1$ respectively)

Three women had normoprolactinaemic galactorrhoea. Their plasma prolactin concentrations and symptoms were unchanged by metergoline. The table summarises the findings in the remaining eight women.

Side effects occurred in seven patients. Changes of mood were a common complaint : four women described depression, which lifted when metergoline was stopped, and one man described feeling detached, relaxed, and happy when the drug was started and again when the dose was increased. In three patients nausea and vomiting necessitated a reduction in dose or discontinuation of treatment. One patient developed a duodenal ulcer.

There was no unexplained change in renal or hepatic function or in the full blood count in any patient taking metergoline, and no patient developed hypopituitarism.

\section{Comment}

In this selected group of patients metergoline lowered the plasma prolactin concentration in all patients with and without identifiable tumours, but normal concentrations were not achieved. The reduction of prolactin concentration in most of the patients was modest compared with that usually effected by bromocriptine.

In six patients galactorrhoea was abolished or a regular menstrual cycle established, or both. Two women conceived while taking metergoline, although one was taking additional treatment (bromocriptine and Pergonal) after metergoline alone proved ineffective.

As metergoline acts predominantly as a serotonin antagonist ${ }^{2}$ it might be expected to have additive or synergistic effects when combined with bromocriptine. Although it has some dopaminergic activity, ${ }^{3}$ this is probably not the mechanism that suppresses prolactin. ${ }^{4}$ Interestingly, the prolactin concentration in one patient was reduced further when $2.5 \mathrm{mg}$ bromocriptine was added to treatment.

We emphasise that metergoline was used only in patients who were unable to tolerate bromocriptine, so the fairly high incidence of side effects may have been because these patients were unduly sensitive. As metergoline reduces the response of adrenocorticotrophic hormone to hypoglycaemia ${ }^{5}$ hypoadrenalism should be considered in patients taking this drug. Metergoline provides satisfactory treatment for many patients unable to tolerate bromocriptine and should be useful in the management of hyperprolactinaemia either alone or combined with a small dose of bromocriptine.

We thank Dr H Sussman of Farmitalia Carlo Erba Limited for supplies of metergoline and Miss B J Bolton for typing the manuscript.

Clinical details of eight women with hyperprolactinaemia, with plasma prolactin concentrations before and during treatment with metergoline

\begin{tabular}{|c|c|c|c|c|c|c|}
\hline \multirow{2}{*}{$\begin{array}{l}\text { Case } \\
\text { No }\end{array}$} & \multicolumn{2}{|c|}{ Mean plasma prolactin (mU/l) } & \multirow{2}{*}{$\begin{array}{l}\text { Tumour evident } \\
\text { on computed } \\
\text { tomogram }\end{array}$} & \multirow{2}{*}{ Galactorrhoea } & \multirow{2}{*}{ Menstrual cycle } & \multirow{2}{*}{ Comments } \\
\hline & Before treatment* & During treatment $\dagger$ & & & & \\
\hline 1 & 1500 & 890 & No & Abolished & Became regular & Conceived \\
\hline $\begin{array}{l}2 \\
3\end{array}$ & $\begin{array}{r}4600 \\
20200\end{array}$ & $\begin{array}{l}2500 \\
1020\end{array}$ & $\begin{array}{l}\text { No } \\
\text { Yes }\end{array}$ & $\begin{array}{l}\text { Abolished } \\
\text { Abolished }\end{array}$ & $\begin{array}{l}\text { Periods started but irregular } \\
\text { Menstruated once while taking }\end{array}$ & Metergoline stopped because of depression \\
\hline 4 & 1640 & $\begin{array}{l}\text { Only took metergoline } \\
\text { for one month }\end{array}$ & Yes & Continued & $\begin{array}{l}\text { metergoline } \\
\text { Remained amenorrhoeic }\end{array}$ & $\begin{array}{l}\text { Depression and vomiting required reduction in dose to } \\
4 \mathrm{mg} \text { twice daily but prolactin not suppressed. Unable } \\
\text { to tolerate additional bromocriptine } 2.5 \mathrm{mg} \text { at night }\end{array}$ \\
\hline 5 & 1950 & 1330 at 3 months & Yes & Reduced & $\begin{array}{l}\text { Periods became regular but } \\
\text { did not ovulate }\end{array}$ & $\begin{array}{l}\text { Metergoline stopped because of nausea and vomiting. } \\
\text { Found to have a duodenal ulcer }\end{array}$ \\
\hline $\begin{array}{l}6 \\
7\end{array}$ & $\begin{array}{r}1800 \\
55000\end{array}$ & $\begin{array}{l}1320 \\
1340\end{array}$ & $\begin{array}{l}\text { Yes } \\
\text { Yes }\end{array}$ & $\begin{array}{l}\text { Continued } \\
\text { Reduced }\end{array}$ & $\begin{array}{l}\text { Remained amenorrhoeic } \\
\text { Remained amenorrhoeic }\end{array}$ & $\begin{array}{l}\text { Developed depression and headache } \\
\text { With addition of bromocriptine and Pergonal to } \\
\text { metergoline she conceived }\end{array}$ \\
\hline 8 & 135000 & 1130 & Yes & Reduced & $\begin{array}{l}\text { Menstruated once: first time } \\
\text { for } 20 \text { years }\end{array}$ & $\begin{array}{l}\text { Had symptoms of hiatus hernia with anxiety and } \\
\text { hyperventilation before treatment }\end{array}$ \\
\hline
\end{tabular}

Mean of three measurements.

+ Mean of concentrations at five, six, and seven months. 
1 Delitala G, Masala A, Alagna S, Devilla L, Lodico G, Lottie G. Metergoline in the inhibition of puerperal lactation. $B r$ Med $\mathcal{F} 1977$; $\mathrm{i}: 744-6$.

Ferrari C, Caldara R, Romussi $M$, et al. Prolactin suppression by serotonin antagonists in man: further evidence for serotoninergic control of prolacin antagonists in man. further evidence for ser.

3 Chiodini PG Luroendocrinology 1978, methergoline on growth hormone and prolactin levels in acromegalic patients. methergoline on growth hormone and pro
$\mathcal{f}$ Clin Endocrinol Metab $1976 ; 43: 356-63$.

4 Besser GM, Delitala G, Grossman A, Yeo T. Metergoline and cyproheptadine suppress prolactin by a non-5-hydroxytryptaminergic, non-dopaminergic mechanism. Br $\mathcal{F}$ Pharmacol 1980;70:5-7.

5 Cavagnini F, Raggi U, Micossi P, DiLandro A, Invitti C. Effect of an antiserotoninergic drug, metergoline, on the ACTH and cortisol response to insulin hypoglycaemia and lysine-vasopressin in man. $\mathcal{f}$ Clin Endocrinol Metab
$1976 ; 43: 306-12$.

(Accepted 28 February 1985)

Royal Liverpool Hospital, Liverpool L7 8XP

I F CASSON, MD, MRCP, senior medical registrar

B A WALKER, MD, FRCP, consultant physician

University of Liverpool, Liverpool L69 3BX

L J HIPKIN, MD, FRCPATH, senior lecturer in endocrine pathology

$P$ E BELCHETZ, MD, FRCP, senior lecturer in medicine

Correspondence to: Dr I F Casson.

\section{Men who steal children}

The stealing of children is a rare offence. d'Orbán described three characteristic patterns in women who steal children-namely, comforting offences, manipulative offences (with the intention of influencing a male partner), and offences by psychotic women. ${ }^{1}$ The associated psychiatric problems include hysterical personality disorder, mental handicap, and schizophrenia ${ }^{12}$ and also pseudocyesis. ${ }^{3}$ Child stealing is generally considered to be a crime committed by women. Until recently, however, most of the offences were committed by men, ${ }^{2}$ and during $1977-82$ the sexes were equally represented ( 34 men and 34 women). ${ }^{4}$ There are no previous reports on men who steal children, but d'Orbán hypothesised that men are likely to steal older children for sexual motives. ${ }^{2}$ We gathered available evidence on child stealing offences committed by men.

\section{Subjects and method}

We inquired from colleagues in special hospitals, secure units, and a London remand prison about men charged with stealing children. We also collected press reports over six months in 1983. We examined four patients: three were charged with stealing children and one with theft of a car, but his admitted intention had been to use the vehicle to abduct a child. We also found two cases reported by the press. The table shows the salient features.

\section{Comment}

This small series of cases is not representative of all men charged with child stealing. Nevertheless, the findings confirm our hypothesis and suggest that men who steal children differ from women in that they abduct older children rather than babies and their motivation is sexual. The four men examined had personality disorders, but, unlike a high proportion of women who steal children, none was mentally ill. All the men were paedophiles and had a preference for children of a specific age and sex. Five had a history of sexual offences against children, and in case 6 the judge's reported remarks also indicated a sexual motive. Two men (cases 1 and 3) had sadistic fantasies about children.

Interestingly, two men (cases 4 and 6) were acquitted because the children had apparently accompanied the men voluntarily and the prosecuting counsel could not prove that the abduction had entailed force or fraud, which was a necessary element of the offence of child stealing under section 56 of the Offences Against the Person Act 1861. Another shortcoming of this law was that it did not apply to a natural parent, although nowadays most cases of abduction of children concern separated or divorced parents who abduct their own children. Until recently, the only legal protection in such cases was for a child to be made a ward of court, but in 1984 the House of Lords ruled that a parent can also be convicted of the common law offence of kidnapping his own child. ${ }^{5}$

The confusing legal position was simplified by the Child Abduction Act implemented in October 1984, which repealed the offence of child stealing under the 1861 Act and created two new offencesnamely, abduction of a child under the age of 16 by a parent if the child is taken out of the United Kingdom without appropriate consent, and abduction of a child by other persons. Whereas the offence of child stealing required proof of force or fraud, the new offence of abduction of a child focuses on lack of consent by the parent or lawful guardian to the removal of the child and therefore provides stronger legal safeguards. The men in cases 4 and 6 who were acquitted of child stealing would probably have been convicted of abduction under the new legislation.

1 d'Orbán PT. Child stealing: a typology of female offenders. British fournal of Criminology 1976;16:275-81.

2 d'Orbán PT. Baby stealing. Br Med f 1972; ii :635-9.

3 d'Orbán PT. Child stealing and pseudocyesis. Br F Psychiatry 1982;141:196-8. 4 Home Office. Criminal statistics England and Wales. London: HMSO, 1977-82. $5 \mathrm{R} v$ D. Law report. The Times 1984 Jun 22:14.

(Accepted 21 February 1985)

Academic Department of Psychiatry, Royal Free Hospital, London NW3 2QG

P T D'ORBÁN, MB, FRCPSYCH, consultant forensic psychiatrist

Maudsley Hospital, London SE5 8AZ

P HAYDN-SMITH, MB, MRCPSYCH, senior registrar in forensic psychiatry

Correspondence to: Dr P T d'Orbán.

\section{Torsade de pointes induced by sotalol despite therapeutic plasma sotalol concentrations}

Sotalol, a $\beta$ blocking agent with additional group III antiarrhythmic properties, prolongs the QT interval in a manner that depends on concentration. ${ }^{1}$ Prolongation of the QT interval by sotalol has been associated with ventricular tachyarrhythmias, but controversy exists over whether it occurs in the absence of high doses $(480 \mathrm{mg}$ and more day), intoxication with sotalol, or renal failure. ${ }^{2}$ Ventricular tachycardia due to prolongation of the QT interval has been reported in a patient taking normal doses of sotalol (320 mg daily), but the concentration of sotalol was not measured. ${ }^{3}$ We report a case of sustained torsade de pointes induced by sotalol that necessitated cardioversion. The patient was taking a normal oral dose of sotalol and had therapeutic plasma sotalol concentrations.

History of offenders

\begin{tabular}{|c|c|c|c|c|c|c|}
\hline Case No & Age (years) & Charge & $\begin{array}{l}\text { Age (years) and } \\
\text { sex of victim }\end{array}$ & Previous sex offences & Outcome & Source \\
\hline 1 & 24 & Child stealing & $8 \mathrm{~F}$ & Four indecent exposures & $\begin{array}{l}\text { Hospital order with restriction } \\
\text { (psychopathic disorder) }\end{array}$ & Special hospital \\
\hline 2 & 29 & Child stealing & $4 \mathrm{~F}$ & $\begin{array}{l}\text { Attempted rape (girl aged 5); } \\
\text { indecent assault (girl aged 8) }\end{array}$ & $\begin{array}{l}\text { Hospital order with restriction } \\
\text { (psychopathic disorder) }\end{array}$ & Secure unit \\
\hline 3 & 26 & Car theft (with intent to abduct girl) & & $\begin{array}{l}\text { Indecent assaults (girls aged } 7 \\
\text { and 8) }\end{array}$ & $\begin{array}{l}\text { Hospital order (psychopathic } \\
\text { disorder) }\end{array}$ & Secure unit \\
\hline 4 & 27 & $\begin{array}{l}\text { Child stealing (three counts), } \\
\text { indecent assault, administering } \\
\text { drugs (diethylpropion) }\end{array}$ & $11,12,13 \mathrm{M}$ & Indecent assault (boy aged 10) & $\begin{array}{l}\text { Acquitted of child stealing. } \\
\text { Convicted of administering } \\
\text { drug }\end{array}$ & Remand prison \\
\hline 5 & 48 & $\begin{array}{l}\text { Child stealing, attempted gross } \\
\text { indecency }\end{array}$ & $9 \mathrm{M}$ & $\begin{array}{l}\text { Numerous offences against } \\
\text { boys }\end{array}$ & Six years' imprisonment & The Times (22 Dec 1983) \\
\hline 6 & 61 & Child stealing & $4,5 \mathrm{~F}$ & Not known & Acquitted & The Times (19 Nov 1983) \\
\hline
\end{tabular}

